\title{
Inner nest homeostasis in a changing environment with special emphasis on honey bee brood nursing and pollen supply
}

\author{
Thomas SCHMICKL, Karl CRAILSHEIM* \\ Department for Zoology, Karl-Franzens-University Graz, Universitätsplatz 2, 8010 Graz, Austria
}

(Received 29 July 2003; revised 5 November 2003; accepted 9 January 2004)

\begin{abstract}
To reproduce successfully, a honey bee colony has to rear brood efficiently. This requires a fecund queen and depends on the coordinated activities of workers in brood care, in foraging, and in maintaining inner nest homeostasis. Maintaining homeostasis involves thermal regulation of the brood area and providing a steady supply of nutrients, which requires building food reserves during favorable weather so that the brood can be well fed even during times of low nutritional influx. The workforce of adult bees is appropriately divided among the required tasks, and the wax comb itself is spatially organized in a way that saves energy and supports brood nursing. The ability to achieve this homeostasis results from a set of individual behaviors and communication processes performed in parallel by thousands of bees. In this review, we discuss these proximate individual mechanisms that lead to the precise regulation of the complex system that is a honey bee society.
\end{abstract}

Apis mellifera / homeostasis / nursing / pollen / self-organization

\section{INTRODUCTION}

The population dynamics of honey bee (Apis mellifera L.) colonies in temperate regions show a characteristic seasonal pattern. Within a few months, the colony's population increases from several thousands of bees in winter up to tens of thousands of adult bees in summer (Bodenheimer, 1937). This mass production of individual bees is the basic process that allows reproduction at the colony level: swarming. Only a strong colony, one having a large number of as-young-as-possible adult bees, has a good chance to divide successfully, thereby achieving reproductive success. In temperate regions the swarming season lasts only for approximately 6 to 8 weeks, so it is necessary for the colony to produce the needed mass of bees within a narrow time window during spring. This timing (early in the flying season) is necessary, because both the new colony founded by the swarm and the old (parent) colony need enough time to regain high levels of resources and bees, to support survival through the winter.

To achieve effective brood production, honey bees precisely control the inner nest conditions (homeostasis) and support rapid brood growth by investing much effort into nursing (inspecting, cleaning, feeding). Usually, a honey bee colony has a huge amount of honey stored inside the hive, but only small amounts of pollen. Because this pollen is the colony's main protein source and the mass production of brood depends strongly on these proteins, there is a special need for the colony to regulate pollen stores adequately. This regulation includes foraging decisions, forager recruitment decisions and regulation of pollen allocation to consumers. There are several distinct

\footnotetext{
* Corresponding author: karl.crailsheim@uni-graz.at
} 
groups of significant protein consumers in the hive: the queen, the larvae, the nurses, the foragers and the drones. In times of bad environmental conditions, when the pollen supply is low, this valuable resource has to be shared differently than in times of good supply. Several feedback loops are involved in this homeostatic regulation system, which also includes the spatial organization of the colony's combs.

This review describes the mechanisms used by honey bees to achieve proper inner nest conditions to allow mass production of brood, and how these mechanisms support supply-anddemand-driven regulation. We especially focus on changes to the inner nest organization as responses to external environmental changes that affect supply, and on the demand-driven regulation of foraging decisions.

\section{REGULATION OF FORAGING}

Honey bee colonies can precisely choose the most effective nectar source by evaluating the energetic foraging costs of each source and the energetic gains derived from each source (Seeley et al., 1991; Seeley, 1994). In addition, experiments have shown that not only the sugar concentration of a nectar source, but also the nectar flow rate influences many behaviors which play an important role in the collective decision-making process: the level of crop filling by foragers (Varjú and Núnez, 1991) and their trophallactic rates after return (Wainselboim and Farina, 2000). Among several pollen sources, bees are able to choose based on pollen-based cues (Pernal and Currie, 2002). We do not cover the source-selection strategies of honey bees in this review, as they are fully reviewed elsewhere (Sumpter and Pratt, 2003).

Each potential forager also has to decide whether to primarily gather nectar or pollen. Many studies have shown that honey bee colonies regulate their pollen foraging according to the current colony demand (Moeller, 1972). When the colony is in need of pollen, a greater fraction of foragers collects pollen (Barker, 1971; Webster et al., 1985; Rotjan et al., 2002). With higher amounts of unsealed brood (which cause a huge pollen demand), foraging gets intensified (Filmer, 1932; Al-Tikrity et al., 1972), and there is a positive correlation between the amount of stored pollen and the amount of brood that is reared (Allen and Jeffree, 1956). Addition of pollen to a hive reduces pollen foraging significantly (Free and Williams, 1971). These facts suggest that foraging effort is regulated according to the current ratio of pollen supply to pollen demand. Fewell and Winston (1992) as well as Weidenmüller and Tautz (2002) demonstrated that after pollen removal both individual foraging behavior and colony-level foraging decisions are adjusted until pollen stores reach their prior level again - that is, that the level of pollen stores is regulated around a homeostatic set point. They also showed that in times of pollen need trophallactic contacts may provide an informational pathway for foragers to asses the current collective pollen status. This is also supported by Janmaat et al. (2000), who found that the experimental addition of pollen into the colonies leads to behavioral changes at both the individual level and the colony level.

Studies have shown that foragers without direct access to the pollen stores can nevertheless make proper foraging decisions if they have trophallactic contacts with brood-nursing bees (Camazine, 1993). This suggests the "brood food theory": that the trophallactic flow throughout the colony represents a communication channel that informs foragers about the current nutritional status of the colony. In times of a low pollen-to-brood ratio (little pollen and relatively many larvae), little or no protein reaches the group of foragers via the trophallactic flow, which stimulates greater pollen foraging. Inversely, proteinaceous trophallaxis has an inhibitory effect on pollen foraging activity. These mechanisms can explain the observed pollen foraging regulation (Camazine et al., 1998). Vaughan and Calderone (2002) showed that segregated foragers adjust their pollen foraging mainly to the number of pollen cells within their reach and that their pollen foraging behavior is not significantly influenced by trophallactic contacts with nurse bees, which feed many unsealed larvae. These two studies do not necessarily contradict each other, as Camazine et al. (1998) showed the presence of an inhibitory effect of trophallaxis on pollen foragers and Vaughan and Calderone (2002) demonstrated the absence of an excitatory effect.

Pankiw et al. (1998) demonstrated that the presence of brood pheromone alone stimulates 
foraging for pollen, suggesting at least a parallel mechanism to regulate demand-driven pollen foraging. Already Jaycox (1970) had shown the influence of queen, larvae and larval extracts on pollen foraging activities. Dreller and Tarpy (2000) showed that foragers inform themselves about the current level of pollen stores and about the current brood status of the colony via personal cell inspections. This study also showed that caged hungry unsealed brood does not stimulate pollen foraging; in fact, the pollen foraging level was even lower in setups with caged brood. From these studies, one has to conclude that if brood stimulates pollen foraging via a brood pheromone, the pheromone works only within very short distances (maybe even requiring direct contact) so that pollen foragers have to have direct access to the unsealed brood. Free (1967) observed that brood stimulated pollen foraging more when foragers had direct access to the brood than when there were single-screen cages around the brood; brood in double-screen cages did not significantly stimulate pollen foraging.

Recently, Pernal and Currie (2001) showed that honey bee colonies respond to changes in the stored pollen quality with a change in pollen forager recruitment but that individual foragers do not change the size or floral species of their individual pollen loads in response to changes in pollen quality.

Many studies have shown that honey bees are able to regulate their pollen foraging accordingly to the demand (brood) state of the colony and according to the supply (stores) state of the colony. The proximate mechanisms allowing bees to assess the ratio of supply to demand have not been demonstrated, but several mechanisms are suggested by various studies: trophallactic interactions, inspections of pollen stores and inspections of brood cells. It is not known which group of workers are the central decision-makers, nurses or foragers. Certainly the full answer may be complex, as bees use more than one information pathway in their pollen foraging decisions and these decisions might involve more than one task group of bees.

\section{DIVISION OF LABOR AND TASK PARTITIONING}

Generally, adult bees perform a variety of tasks in the hive. The task selection of an indi- vidual worker bee depends on several factors: her age, her past experiences, the current age demography and the current demands of the colony. Intracolonial homeostasis is associated with a variety of tasks: foraging for nutrients, storing and processing nutrients, using the collected nutrients to feed larvae and adult bees, building new combs, cleaning and preparing old used combs, heating and cooling. Seeley (1982) gives a good overview of honey bee worker tasks, their age-dependent performance probability and the locations within the hive where each task tends to be performed. Anderson (1998), Anderson and Ratnieks (1999) and Ratnieks and Anderson (1999) discuss the difference between division of labor and task partitioning. Division of labor can be seen as allocating several distinct tasks among distinct cohorts of bees. In a honey bee colony, this is an age related process called age polyethism. In contrast to that, task partitioning divides one task into several sub-tasks, executed sequentially by different groups of bees. Both processes need to be flexible, as the environment and the age structure of colonies can change, but task partitioning places an additional demand of synchronization and coordination among the bees performing the sub-tasks.

Many early studies showed that younger, middle-aged and older workers choose among age-characteristic tasks (Rösch, 1925; Lindauer, 1952; Sakagami, 1953). Later studies revealed that the division of labor in honey bees is primarily influenced by the colony's total population (= workforce), by its age distribution and by its current workload (e.g., the ratio of brood to nurses). Winston and Punnett (1982), as well as Winston and Fergusson $(1985,1986)$ showed that the total colony population size and not the amount of brood influences the starting age of foraging. Huang and Robinson (1996) demonstrated that changes in the age distribution also affect division of labor significantly. Also, the influence of genetic predisposition (Rothenbuhler and Page, 1989; Pankiw and Page, 2001) and the influence of hormones (Robinson, 1987; Robinson et al., 1989; Robinson et al., 1992) on division of labor have been studied intensively.

The population of a honey bee colony in a good summer can include up to 75000 individuals, approximately $64 \%$ adult bees and $36 \%$ brood. The brood consists of eggs (5\% of the 
total colony population), larvae (10\%) and pupae $(21 \%)$, estimated from Bodenheimer (1937) and Fukuda (1983). Seeley (1982) mentioned that bees in the youngest age class $(0-$ 2 days) are associated with brood production by cleaning the empty brood cells to prepare the cells for reuse. The next older age class associated with brood production is the class of nurse bees. These bees feed the larvae massively, as larvae need a constant supply of nutrients. According to Haydak (1963a), nurse bees typically are from 5 to 16 days old. He showed that even 40-98 days old bees are able to rear brood, though the bees they produced had physiological deficiencies.

In summary, only the right allocation of tasks among the available workforce can ensure the needed inner nest homeostasis to support efficient brood production. The work in the colony is distributed among several age-distinct cohorts of bees (division of labor and age polyethism). Several working processes are sequentially performed by distinct groups of bees (task partitioning). Throughout a honey bee year, there are usually high fluctuations in the outside environment. The age structure of the colony also changes typically throughout the year. Thus a dynamic workload balance is needed, because only flexible division of labor and flexible task partitioning can ensure stable inner nest homeostasis under such conditions.

\section{THE FLOW OF NUTRIENTS WITHIN THE COLONY}

Nurse bees ingest most of the colony's collected pollen (Crailsheim et al., 1992), which represents the main protein source of the colony. The nurse bees digest the pollen and nectar and convert it into a fluid called "jelly", secreted by their hypopharyngeal glands (Hanser and Rembold, 1964). The jelly is rich in proteins and contains several kinds of sugar (Brouwers, 1984). The nurses feed jelly to the brood, to the queen, to drones and to adult bees performing other tasks, especially to foragers (Crailsheim, 1992). Thus jelly represents an important nutrient for immature and adult bees (Crailsheim, 1990). Experiments showed that in a single night up to $16 \%$ of all bees received proteins from 100 nurses injected with $14 \mathrm{C}$ labeled phenylalanine, and that up to $25 \%$ of the marked phenylalanine went to adult worker bees, mainly to foragers (Crailsheim, 1991, 1992).

In addition to the interadult feedings of the gland-produced jelly, there is an interadult feeding network for nectar throughout the colony; it uses the stomach as a short-term storage place. Homecoming foragers hand their nectar load over to storage bees, a group of middle aged bees (12-18 days old; see Seeley, 1989) which transport the nectar to available empty cells and process it afterwards into honey (Crailsheim et al., 1999). Nixon and Ribbands (1952), as well as DeGrandi-Hoffmann and Hagler (2000), demonstrated that the incoming nectar is quickly distributed within the hive among all age groups of working bees and that it is also fed to the larvae.

The length of the queuing delay of homecoming nectar foragers waiting for available nectar receivers is used by foragers to acquire information about the current colony status (Seeley, 1989; Seeley and Tovey, 1994) and the precision of this measure is increased by making multiple nectar transfers (Hart and Ratnieks, 2001). The properties of this queuing system were studied via mathematical models in a variety of studies (Anderson, 1998; Anderson and Ratnieks, 1999; Ratnieks and Anderson, 1999). De Marco and Farina (2003) showed that homecoming foragers not only offer food to receivers, they also exhibit begging behaviors to acquire information about the foraging decisions of their nest mates. Crailsheim et al. (1999) showed that food storage bees are very active during daytime in times of good nectar income, making frequent trophallactic contacts on the dancefloor area of the hive. At night and on days with simulated bad weather conditions, they rest almost inactive in the brood area or in the storage area, and nearly all of their trophallactic contacts occur within the broodnest area. This group of bees shows a significant diurnal rhythm due to the dependence of their task on nectar influx.

Free $(1957 \mathrm{a}, \mathrm{b})$ described the behavioral aspects of food offering and food begging, also demonstrating that bees about to give food have a significantly higher load in their nectar stomach than bees about to receive food. Moritz and Hallmen (1986) showed the age dependency of the trophallactic activities, 
while Schulz et al. $(1998,2002)$ demonstrated the heavy influence of colony status (starved or not) on the trophallactic behaviors and social interactions prior to the onset of early foragers. Korst and Velthuis (1982) reported individual differences in the likelihood that a bee begs for or offers food in trophallaxis, and they suggest that food transfer is not the main factor in trophallactic contacts. They place trophallactic behavior in the context of the localized social environment and its influence on task selection.

Food exchange between adult bees (trophallaxis, see Crailsheim, 1998) involves nectar, honey and pollen-derived jelly. These nutrients are also fed from adult bees to larvae and (personal observations) sometimes also "stolen" from larvae by adult bees. In addition, there is also a strong nutrient flow to and from food storage cells. Each transaction in this very complex network of nutrient flow can provide information needed to regulate the workload balance. The available information is not only the nutritive value of the exchanged food, but also behavioral aspects of the exchange, for example trophallactic frequencies or queuing delays, as mentioned in the previous section (regulation of foraging). From our own studies (Renner et al., 2003) we know that it is difficult for researchers to fully interpret trophallactic behaviors: through the glass wall of an observation hive, the observer cannot measure the amount of exchanged food, nor determine what kind of food is exchanged; in a laboratory setup, these data can be gathered at least in part, but the social context of the "full hive" is missing, and that may be crucial.

\section{REGULATION OF NUTRIENT STORES}

Foraging for pollen and nectar, the two main sources of nutrients of a honey bee colony, is regulated in a demand-driven way. While nectar is collected in excess due to the fact that a huge reserve of honey is needed for overwintering, pollen is managed around a level that represents a reserve for only a few days. Blaschon et al. (1999) showed that just a few days of rain cause an almost total loss of pollen stores, while honey stores are only lowered by a few percent. They also documented a reduction in the daily pollen losses as the rain periods proceeded, suggesting the existence of mechanisms that save resources by somehow cutting the larval demand.

Hellmich and Rothenbuhler (1986a) described different genetic lines, one that regulates pollen stores at a high level and another that regulates them at a low level, but both lines exhibited demand-driven regulation when brood periods were compared with broodless periods. The rate of usage of pollen was the same for both lines; for both it intensified in times with open brood (see also Hellmich and Rothenbuhler, 1986b). Apparently, in both genetic lines, the larvae consumed pollen-derived proteins at the same rate, but different lines preferred different sized reserves of pollen. The genetic predisposition to collect pollen or honey was also described by Waldbauer and Friedman (1991).

Several studies in the laboratory of R. Page were conducted using strains derived from selection experiments comparable to those performed by Hellmich and Rothenbuhler (Pankiw et al., 2002). These experiments proved again that the pollen hoarding behavior of honey bees is a selectable trait (Page et al., 1995). Page and Fondrk (1995) demonstrated that the "high pollen strains" have a higher proportion of foragers returning with pollen. In the third generation, these strains stored 6 times more pollen than the so called "low pollen strains", but they also produced a significantly lower amount of brood, due to spatial limitations of the brood space caused by the high number of pollen cells. Pankiw and Page (2001) showed that the bees of the "high pollen strain" differed in several important ways from the "low pollen strains" and from "wild-type strains". They were more sensitive, at the colony level, to the addition of brood or the removal of pollen stores. The workers tended to begin foraging at a younger age, the individuals were more likely to collect pollen, and their nectar foragers returned with smaller nectar loads.

The storage of pollen does not require food storage bees. Homecoming pollen foragers deposit their loads into available cells by themselves. According to Dreller and Tarpy (2000), pollen is stored mostly in areas very near to or even inside the broodnest.

In the next section, we describe how these pollen stores are used by the nurse bees, which 
work in the broodnest area. The storage of the pollen near unsealed brood supports proper brood nest homeostasis in several ways: nurse bees can quickly and easily access these pollen stores, and pollen foragers can perceive stimuli both from brood and from pollen cells within a concentrated, distinct area, which would make it possible for them to make foraging decisions based on the ratio of pollen supply to pollen demand (see the section "regulation of foraging").

\section{NURSING OF BROOD}

In a queenright honey bee colony, almost all brood that reaches the capped stage is the offspring of the colony's queen. Although there are always some worker-laid eggs on the comb, they are generally removed by worker policing mostly within one day (Ratnieks, 1993). During its larval stage, which lasts for approximately $5 \frac{1}{2}$ days, an immature honey bee needs steady care from adult bees. The adult bees spend enormous effort in brood care. Wax builders have to build up enough combs to allow successful mass production of brood, as lowered brood space decreases population growth (e.g., Simpson and Greenwood, 1975). Workers inspect cells containing larvae to control the nutritional status as well as the hygienic status of the brood. Detection of ill or dead brood will lead to quick removal (Free and Winder, 1983; Arathi et al., 2000). Detection of hungry larvae forces the inspecting bee to feed the larvae, which they do by depositing a certain fraction of gland secretion or (with older larvae) by providing pollen or honey (cf. Haydak, 1970). Pollen directly fed to the brood constitutes only approximately $5 \%$ of all protein-containing brood feedings (Babendreier et al., 2004, in press). Harbo (1993) calculated the overall investment into brood nursing using honey as the currency: $\mathrm{He}$ found that bees used $121 \mathrm{~g}$ of honey (that is, the energy stored in this amount of honey) to raise one thousand adults from an age-mixed brood comb, and about $163 \mathrm{mg}$ of honey to rear one egg to the pupal stage.

The collective effort of the adult bees maintains the brood area at an almost constant temperature around $36^{\circ} \mathrm{C}$ by several mechanisms: active heating, cooling with water, fanning and heat shielding (Hess, 1926; Southwick, 1987, 1991; Starks and Gilley, 1999). In this environment, larvae grow very fast and increase their body mass almost 1300 -fold (from $0.11 \mathrm{mg}$ to $159 \mathrm{mg}$ ) within 51/2 days (Stabe, 1930; Wang, 1965), showing exponential growth within the first 5 days. This growth pattern of larvae has also been shown for bumble bees (Ribeiro, 1994). Almost linearly correlated with the mass gain of larvae, the oxygen consumption of larvae shows the same age-dependent pattern (unpublished data), suggesting that older larvae have more body mass, a higher metabolic rate and a higher nutritional demand. This is strengthened by several studies (Lineburg, 1924; Lindauer, 1952) that found very similar age-dependent patterns of cell inspections and of larval feedings performed by nurse bees.

Another important factor is the ratio of nurses to larvae: Eischen et al. (1982, 1983) established several colonies with different worker-larvae-ratios. A higher worker-to-larvae ratio led to lower pollen consumption per worker and to a higher life-span of the offspring. Surprisingly, colonies with higher "workload" per nurse showed a better brood rearing efficiency than bigger colonies with lower workload per nurse, which was also shown by Harbo (1986). But as the nurses with higher workloads became older, their nursing ability diminished more strongly than it did in nurses who faced a lower workload (Eischen et al., 1984).

Nurse bees perform significantly more frequent inspections of brood cells containing eggs and larvae (Huang and Otis, 1991a) compared to empty cells. The frequent cell inspections of thousands of larvae performed in parallel by thousands of nurse bees can be interpreted as an optimized sampling method, as such multiple inspections might decrease the standard deviation of the mean of the gathered information. The same effect has been discussed by Hart and Ratnieks (2001) in the context of multiple nectar transfers from homecoming foragers to nectar receivers. The frequency and duration of feeding acts are mostly determined by the caste and the age of the nursed larva (Lindauer, 1952; Beetsma, 1985; Brouwers et al., 1987) and by the age of the adult bee (Smith, 1974). Huang and Otis (1991b) showed that the previous nursing history of the larva also plays an important 
role: larvae that were hungrier because of a prior caging period were fed in a favored manner. Comparable findings were reported by Ribeiro et al. (1999) with larvae of Bombus terrestris. Also, Schmickl and Crailsheim (2002) and Schmickl et al. (2003) showed that the overall colony status influences the frequency and duration of cell inspections and nursing acts. They suggested that larvae produce a nursing stimulus and an inspection stimulus (see also Huang and Otis, 1991b), while nurse bees have a variable nursing threshold and a variable inspection threshold. At least with queen larvae, Le Conte et al. (1995) could show that brood pheromones can affect nursing behavior significantly. The strength of the stimulus a larva is able to emit depends presumably on its caste, stage, age and on its nutritional status, while the height of a nurse's feeding threshold is presumably influenced by her nutritional status. Schmickl and Crailsheim (2002) and Schmickl et al. (2003) demonstrated that the neglecting of larvae in times of pollen dearth is precisely dependent on the overall colony ratio of pollen supply to pollen demand: when pollen was scarce nursing efforts were gradually shifted away from young larvae and focused on the very old larvae, which were already close to the final capping.

Several early studies have shown that bad weather periods influence the ability of a honey bee colony to effectively produce brood. During bad weather there is a decrease in pollen and nectar influx. Szabo (1980) showed that both flight activity and colony weight gain correlate with weather factors. Colonies equipped with pollen traps (and therefore having minimal pollen influx) produced significantly less brood than colonies without traps (Webster et al., 1985). Dietz and Stephenson (1975) showed that only colonies with access to a certain amount of fresh pollen are able to perform successful brood rearing; see also Haydak (1935, 1963b). Low pollen stores in a colony also reduce the age bees start to forage and their adult life span, when they were infested with Varroa jacobsoni as pupae, thus influencing age demography and temporal task scheduling (Janmaat and Winston, 2000). Several experiments (Doull and Standifer, 1969, 1970) showed that nursing bees are attracted to pollen and even to some extracts of pollen.
Any loss of brood, whether caused by bad weather leading to low pollen stores or by other factors, directly affects the age structure of the colony within days or weeks. As this age structure directly influences the division of labor, which again can affect the nursing of the brood, the situation is characterized by a (delayed) feedback loop. The society's plasticity and its ability to reorganize labor allocation allow it to compensate for the demographic effects, preventing severe damage to the colony. Nevertheless, this compensation takes time, so that environmental fluctuations represent costs (in terms of colony fitness) to the colony. The next section describes in detail how such brood losses can be induced by a fluctuating environment.

\section{CANNIBALISM AND EARLY CAPPINGS}

Bad or cold weather, reducing the pollen influx, leads to brood loss, which soon leads to a decline in the number of nurses. As nurses have to rear more brood per nurse, this leads to further brood loss and to bees that develop with physiological deficiencies (Dustmann and von der Ohe, 1988). Such brood losses are often due to brood cannibalism performed by adult bees; middle aged larvae and eggs are most likely to be eaten (Schmickl and Crailsheim, 2001). Blaschon et al. (1999) have shown that in periods of experimentally prevented foraging, larval demography changed within days. After five days of artificial rain, almost all older (and larger) larvae disappeared in the unsealed broodnest, thus suggesting that the nurse bees react to a drop in pollen influx by reducing the larval demand. Several possible mechanisms were suggested in this paper: cannibalism of larvae in certain age groups, or delayed developmental periods resulting from underfeeding of brood or from lowered broodnest temperatures.

Blaschon et al. (1999) also discussed a stoppage of egg laying by the queen. It seems clear that a cessation in egg laying cannot explain the observed quick decrease in the number of old larvae: this decrease in the older larvae population was seen shortly after the start of a period of simulated rain, whereas it would take about eight days for a cessation in egg laying 
to directly affect the number of older larvae. Also Schmickl et al. (2003) showed that such artificial rain periods did not necessarily decrease the egg laying of the queen significantly.

The studies of Schmickl and Crailsheim $(2001,2002)$ have shown that an experimental elimination of pollen influx leads not only to the neglecting of younger larvae by nursing bees but also to increased cannibalism of middle aged larvae, which are very likely to be underfed after being neglected as young larvae. Although the oldest larvae (aged $4 \mathrm{~d}$ and $5 d$ ) would represent a richer protein source for the bees and more feeding efforts could be saved by cannibalizing them, these larvae were seldom eaten, a fact that was already described by Woyke (1977). This study and that of Garofalo (1977) also showed a seasonal effect on brood loss. Newton and Michl (1974) reported that manually uncapped pupae are more unlikely to be removed with increasing age. Webster et al. (1987) showed that nutrients from cannibalized larval tissue were used to produce larval food for queen cups, while Webster and Peng (1987) reported reuse of larval tissue for trophallaxis and for hypopharyngeal gland secretions. Weiss (1984) was able to force bees to rear brood successfully while their only protein source consisted of larvae to cannibalize.

Schmickl and Crailsheim (2001) also noted a second mechanism that decreased the amount of unsealed brood to feed: early capping of old larvae. Although this decreases the pressure of larval demand, this mechanism has a certain cost for the colony: the larvae that reached the final capping stage with a low pollen supply showed the physiological impact of low feedings, manifested in lower body weights and lower relative protein content, thus suggesting a shorter adult life span for those bees. Both strategies, cannibalism and early capping, influence the age demography in a delayed way, eventually influencing age task scheduling.

\section{SPATIAL ORGANISATION OF THE BROODNEST}

A honey bee nest consists of a set of combs organized in a characteristic manner, allowing proper thermoregulation of the brood area
(Himmer, 1932; Villa et al., 1987; Southwick and Heldmaier, 1987; Southwick, 1987, 1991; Starks et al., 2000) and minimizing the distances needed for transporting food: a central area filled with brood, surrounded by empty cells so that the broodnest can grow, in turn enclosed in a ring of cells containing pollen, guaranteeing the easiest transport to bring the pollen into the broodnest. The remaining part of the comb (the outer rim) is filled up with honey. In contrast to early assumptions that this spatial organization arises "by lead", somehow dictated by the queen, Camazine (1991) described simple individual processes that can result in the observed spatial organization. Seeley (1982) shows the strong interdependence of task performance and the spatial distribution of task-associated workloads: Bees of one age-class perform a variety of tasks, which are mostly localized within the same region in the hive. Camazine et al. (1990) describe a mathematical model that can predict broodnest spatial organization, as shown by simulation results. The assumptions of this model are:

1. The queen is more likely to deposit additional eggs near existing brood.

2. Stored nectar (or honey) and pollen are more likely to be consumed near unsealed brood.

3. The daily turnover rate of pollen is much higher than the daily turnover rate of nectar (or honey).

4. The colony collects and uses more nectar than pollen.

5. Both nectar and pollen are deposited randomly around the comb.

6. A cell can only contain one kind of resource (honey/nectar, pollen or brood).

Schmickl et al. (2003) showed, that in times of bad nutrient income, the queen maintains her usual egg laying rate but reduces her walking activity significantly. This locally concentrated egg laying behavior might compensate for the temporary "holes" in the broodnest that arise from the higher brood cannibalism during conditions of low food availability (Schmickl and Crailsheim, 2001). While Free (1960) reported an age-specific homogeneity of nurse bee distribution throughout the open broodnest, Furgala and Boch (1961) found a spatial age dependency of nurse bees: Younger nurses (1-10 days) tend to localize themselves 
preferentially in areas containing young worker larvae, while older nurses (11-20 days) are equally distributed throughout areas of worker larvae of all ages (and queen larvae, if any are present). Smith (1974) demonstrated preferential nursing of worker larvae compared to queen cups by very young workers (1-5 days), an equal nursing of worker larvae and queen larvae by middle aged nurses (6-10 days) and a steady decline of visits to worker larvae by older bees.

The faster consumption of pollen adjacent to open brood was empirically shown by the studies of Taber (1973) and Camazine (1991). Doull (1974) showed that bees move randomly in search of pollen and are directly guided to cells containing pollen only within a small surrounding area. He suggests that near open brood, pollen is readily consumed by nurse bees. In the model of Camazine et al. (1990) and Camazine (1991) it was assumed that returning foragers and food-storage bees deposit their loads randomly within the comb. As the simulated comb represents a central brood comb, this is not in conflict with the findings of Dreller and Tarpy (2000), who showed that returning pollen foragers preferentially deposit their pollen loads in frames containing open brood, thus again minimizing transport distances. By using a novel marker protein and immunosorbant assay, DeGrandiHoffman and Hagler (2000) proved that nectar loads are equally (randomly) distributed in brood areas and storage areas and quickly (within $2 \mathrm{~h}$ ) distributed among nurses and brood.

The often observed ring of pollen around the open broodnest can be interpreted as a logistic optimization, representing a short-term reserve of nutrients as close as possible to areas of high consumption. This might be needed for pollen and not for honey or nectar, because a shortterm reserve of nectar is almost always present in the collective stomach of all workers and can be easily kept at a collective homeostatic set point through trophallactic interactions among adult bees.

The brood population itself is not as constant as assumed in the simulation of Camazine et al. (1990): even under normal nutritional and thermal conditions, approximately $15 \%$ of the brood on the central frame disappear (die) before the capped stage. At the outer edge of the broodnest, the losses increase; they were up to approximately $54 \%$ when the brood frame was placed outside of the main broodnest (Fukuda and Sakagami, 1968). Such brood losses were described by Merill (1924) and Myser (1952). Woyke (1988) reported a basic mortality of approximately $7 \%$ for the larval stage under normal conditions, which is consistent with the findings of Garofalo (1977). Under stress conditions (Schmickl and Crailsheim, 2001), even higher brood losses have been observed.

We think that the broodnest itself plays an important role in the ability of honey bees to regulate proper nest homeostasis. It is the place where the queen's egg laying determines the future age structure of the colony and where the brood consumes the main part of the nutrients and the place where the climate is most tightly controlled. In addition, it is the only place where resource stores and consumers are close enough to interact and to be perceived by adult bees. It is the center of the trophallactic network and a storage place for brood-derived proteins. Even though we believe the nest homeostasis of honey bees to be decentralized and self-organized, we think that the major part of these self-organizational processes is working within the distinct area of the broodnest. This is supported by the fact that the spatial organization of the broodnest itself is an ultimate result of the proximate mechanisms that lead to this homeostasis. As we have shown, the published explanations of how this spatial organization evolves over time are not consistent with all findings in the literature, especially not with brood losses and moving patterns of the queen in times of influx fluctuations.

\section{CONCLUSION}

To summarize, the protein available in the colony seems to be regulated around a homeostatic set point via several mechanisms: under normal conditions, when pollen foraging is possible, changes in foraging recruitment and individual workload regulate the pollen stores, maintaining a fairly constant level that makes possible the required nursing of colony members. Increases in protein demand are answered by the colony with an increase in pollen foraging activity. The information about the current ratio of pollen demand to pollen stores is 
gathered in multiple ways: through direct inspections of pollen cells, through perception of brood-produced pheromones and through trophallactic interactions between brood-nursing bees and foraging bees.

If bad environmental circumstances (e.g., bad weather) prevent bees from collecting pollen, the workers reduce larval protein demand through brood cannibalism, through early capping of older larvae and by focusing nursing efforts on older larvae while neglecting younger larvae. These strategies influence the spatial organization and the later age demography of the colony, thus influencing the age polyethism, after a certain delay.

The enrichment of the trophallactic flow with protein derived from larval tissue can be interpreted as an attempt to regulate the mean "collective protein level" of adult bees around a homeostatic set point. This is a distributed regulatory system driven by the ratio of pollen supply to pollen demand. The broodnest area itself plays an important part within this system: It is spatially structured to support brood nursing with high efficiency, and the brood it contains represents a high-level consumer of proteins as well as an enormous reserve of proteins. As the hunger state of the brood and its age demography does not change very quickly, one could also interpret the broodnest as a shared collective memory, as it is described by Thierry et al. (1996), like a blackboard. The broodnest status is perceived by many nurses in parallel, and the perceptions influence nursing behaviors, which in turn influence the broodnest status. Such a self-reading/self-writing system is described in detail in Kugler and Turvey (1988). One larva gets inspected and nursed by many different nurses, and each nurse inspects and feeds many larvae, thus the collective information gets averaged quickly, just like the information shared via the trophallactic network.

The self-organization of the brood nest combs supports quick intracolonial reactions to changes in the nutrient influx, while the dense distribution of nurse bees in the brood area and their frequent inspections and trophallactic contacts improve the precision of this demanddriven regulation system through a multiple sampling process.

\section{ACKNOWLEDGEMENTS}

We thank J. Vollmann for her assistance in the exploration of literature. We also thank R. Nowogrodzki for his critical reading of the manuscript and for linguistic corrections. The writing of this article was supported by the "Fonds zur Förderung der Wissenschaftlichen Forschung (FWF)", project No. P15961-B06. This article was sponsored by the EU-funded project (IP) I-SWARM, IST FET-open Project 507006.

Résumé - Comment les colonies d'abeilles, dans des conditions changeantes d'environnement, maintiennent-elles l'homéostasie du nid ? régulation de l'élevage de couvain et des réserves de pollen. Une colonie d'abeilles domestiques (Apis mellifera $\mathrm{L}$.) produit plusieurs dizaines de milliers d'individus dans une année. Pour rendre possible cette énorme production de couvain les abeilles régulent de façon très précise les conditions internes du nid (homéostasie). Une température élevée et constante du nid à couvain favorise un développement rapide du couvain, dont les stades larvaires sont approvisionnés régulièrement en nourriture par des milliers de nourrices. Ce nourrissage intensif des larves ne peut être obtenu que par un approvisionnement suffisant de la colonie en pollen, le pollen représentant la principale source de protéines pour la colonie. Les réserves de pollen de la colonie doivent être maintenues par régulation homéostatique à une valeur qui correspond à la consommation de quelques jours : réduction manuelle de pollen, fortes quantités de couvain ou trappes à pollen conduisent à une activité intensifiée de récolte de pollen, d'un côté au niveau de la colonie par l'augmentation du nombre de butineuses de pollen, d'un autre côté au niveau individuel par l'augmentation des activités de récolte du pollen.

La régulation de l'activité de récolte du pollen s'effectue par plusieurs mécanismes : par inspection directe des cellules renfermant le pollen, par perception des phéromones de couvain et par contacts trophallactiques entre nourrices et butineuses. Le réseau trophallactique représente un système de communication complexe à travers lequel l'information sur l'état actuel de la ruche atteint très rapidement toutes les abeilles.

Dans les périodes où les conditions climatiques défavorables empêchent que les réserves de pollen soient régulées du côté des entrées, une régulation parallèle se met en place du côté des sorties (consommation) : lorsque l'approvisionnement en pollen est mauvais, les nourrices alimentent moins bien le couvain et réduisent le nombre de consommateurs par le cannibalisme et une operculation plus précoce, ce qui provoque des déficits physiologiques chez le couvain.

Le nid à couvain est peuplé principalement de nourrices qui, par leurs inspections fréquentes des cellules, déterminent l'état nutritionnel des larves et 
réduisent leur faim s'il y a lieu en leur fournissant de la bouillie larvaire. Le fait que des milliers de nourrices inspectent des milliers de larves conduit vraisemblablement à une meilleure vue d'ensemble de la relation du moment entre offre (réserves de pollen) et consommation. Chaque nourrice vérifie l'état de centaines de larves et chaque larve est inspectée et nourrie par des ouvrières nombreuses et différentes. Ainsi chaque nourrice perçoit indirectement et différés dans le temps les effets des actions de soin au couvain (et donc les états internes) prodiguées par des milliers d'autres nourrices.

Les cadres de couvain présentent une organisation spatiale caractéristique : la surface du couvain est entourée d'une première couronne de cellules vides, qui lui permet de s'accroître ultérieurement, puis d'une seconde couronne de cellules remplies de pollen, où la ressource la plus importante est stockée tout près de ses consommateurs ; cette disposition spatiale d'efficacité croissante est obtenue par des interactions simples entre abeilles adultes avec le couvain ou les cellules vides. C'est aussi un phénomène émergent d'auto-organisation.

Le système global de la «colonie d'abeilles » est régulé de façon extrêmement complexe. Le nid à couvain joue lui-mêle un rôle central dans la régulation de l'homéostasie interne. Les nourrices agissent en même temps comme éléments de régulation et de mesure, tandis que les larves représentent en même temps les consommateurs de protéines et les réserves de protéines.

\section{Apis mellifera / homéostasie / soin au couvain / pollen / auto-organisation}

Zusammenfassung - Wie Bienenkolonien bei wechselnden Umweltbedingungen die NestHomöostase aufrecht erhalten: Die Regulation der Brutpflege und des Pollenvorrates. Eine Honigbienenkolonie produziert im Laufe eines Jahres mehrere zehntausend Nachkommen. Um diese enorme Brutproduktion zu ermöglichen, wird die innere Homöostase der Kolonie genauestens geregelt. Eine konstant hohe Brutnesttemperatur fördert eine rasche Entwicklung der Brut, welche im Larvenstadium von tausenden Ammenbienen ständig mit Futter versorgt wird. Diese intensive Larvenfütterung ist nur bei einer ausreichenden Pollenversorgung der Kolonie aufrecht zu erhalten, da Pollen die Haupteiweißquelle der Bienenkolonie darstellt. Die Pollenreserven der Kolonie werden homöostatisch um einen Sollwert geregelt, welcher eine Verbrauchs-Reserve für einige Tage darstellt: Manuelle Pollenreduktionen, hohe Brutmengen oder Pollenfallen führen zu intensivierter Pollensammelaktivität, einerseits auf Kolonieebene durch eine Steigerung der Zahl der Pollensammlerinnen, andererseits auf Individualebene durch eine Steigerung der Pollensammelaktivitäten.

Die Regelung der Pollensammelaktivität erfolgt über mehrere Mechanismen: Durch direkte Inspek- tion der vorhandenen Pollenzellen, durch die Wahrnehmung von Brutpheromonen und durch trophallaktische Kontakte zwischen Ammenbienen und Sammelbienen. Das trophallaktische Netzwerk stellt ein komplexes Kommunikationssystem dar, durch welches Informationen über den aktuellen Stockzustand sehr schnell alle Bienen erreichen.

In Zeiten, in denen ungünstige Witterungsverhältnisse eine Regelung der Pollenvorräte auf der Eintragsseite verhindern, greift eine parallele Regelung auf der Verbraucherseite: Bei schlechter Pollenversorgung füttern die Ammenbienen die Brut schlechter und reduzieren die Verbraucher durch Kannibalismus und durch früheres Verdeckeln, was $\mathrm{zu}$ physiologischen Defiziten der Brut führt.

Das Brutnest wird vor allem von Ammenbienen bevölkert, welche durch ihre häufigen Zellinspektionen den Hungerzustand der Larven ermitteln und diesen gegebenenfalls durch Abgabe von Futtersaft verringern. Die Tatsache, dass einerseits tausende Ammenbienen tausende von Larven inspizieren, führt vermutlich $\mathrm{zu}$ einem verbesserten "Gesamtüberblick" über das aktuelle Verhältnis zwischen Angebot (Pollenvorräten) und Verbrauch. Jede Amme prüft den Zustand von hunderten Larven und jede Larve wird von zahlreichen verschiedenen Ammen inspiziert und gefüttert. Indirekt nimmt somit jede Amme auch zeitverzögert die Auswirkungen der Brutpflege-Aktionen (und damit die inneren Zustände) von tausenden anderen Ammen wahr.

Die Brutwaben weisen eine charakteristische räumliche Organisation auf: Die Brutfläche ist von einem Kranz mit leeren Zellen umgeben, was ein weiteres Wachstum der Brutfläche ermöglicht. Ein weiterer Kranz von pollengefüllten Zellen umgibt die Brutfläche, wodurch die wichtigste Ressource sehr nahe am Hauptort ihres Verbrauches gelagert wird. Diese effizienzsteigernde räumliche Ordnung entsteht durch einfache Interaktionen zwischen adulten Bienen mit der Brut und mit den Wabenzellen, sie ist also ein emergentes Phänomen der Selbstorganisation.

Das Gesamtsystem "Bienenvolk" ist äußerst komplex reguliert, wobei das Brutnest selbst eine zentrale Rolle in der Regulierung der inneren Homöostase spielt. Ammenbienen agieren dabei gleichzeitig als Stell- und Meßglied, während die Larven gleichzeitig Proteinverbraucher und Proteinreserven darstellen.

\section{Honigbienen / Homöostase / Brutpflege / Pollen / Selbst-Organisation}

\section{REFERENCES}

Allen M.D., Jeffree E.P. (1956) The influence of stored pollen and of colony size on the brood rearing of honeybees, Ann. Appl. Biol. 44, 649656. 
Al-Tikrity W.S., Benton A.W., Hillman R.C., Clarke W.W. Jr. (1972) The relationship between the amount of unsealed brood in honeybee colonies and their pollen collection, J. Apic. Res. 11, 9-12.

Anderson C. (1998) Simulation of the feedbacks and regulation of recruitment dancing in honey bees, Adv. Complex Syst. 1, 267-282.

Anderson C., Ratnieks F.L.W. (1999) Task partitioning in insect societies. I. Effect of colony size on queueing delay and colony ergonomic efficiency, Am. Nat. 154, 521-535.

Arathi H.S., Burns I., Spivak M. (2000) Ethology of hygienic behaviour in the honey bee Apis mellifera L. (Hymenoptera: Apidae): Behavioural repertoire of hygienic bees, Ethology 106, 365-379.

Babendreier D., Kalberer N., Romeis J., Fluri P., Bigler F. (2004) Pollen consumption in honey bee larvae: a step forward in the risk assessment of transgenic plants, Apidologie 35, 293-300.

Barker R.J. (1971) The influence of food inside the hive on pollen collection by a honeybee colony, J. Apic. Res. 10, 23-26.

Beetsma J. (1985) Feeding behaviour of nurse bees, larval food composition and caste differentiation in the honey bee, in: Hölldobler B., Lindauer M. (Eds.), Fortschritte der Zoologie 31: Experimental Behavioral Ecology, G. Fischer Verlag, Stuttgart NewYork, pp. 407-410.

Blaschon B., Guttenberger H., Hrassnigg N., Crailsheim K. (1999) Impact of bad weather on the development of the broodnest and pollen stores in a honeybee colony (Hymenoptera: Apidae), Entomol. Gen. 24, 49-60.

Bodenheimer F.S. (1937) Studies in animal populations. II. Seasonal population-trends in the honeybee, Q. Rev. Zool. 12, 406-425.

Brouwers E.V.M. (1984) Glucose/fructose ratio in the food of honeybee larvae during caste differentiation, J. Apic. Res. 23, 94-101.

Brouwers E.V.M., Ebert R., Beetsma J. (1987) Behavioural and physiological aspects of nurse bees in relation to the composition of larval food during caste differentiation in the honeybee, $\mathrm{J}$. Apic. Res. 26, 11-23.

Camazine S. (1991) Self-organizing pattern formation on the combs of honey bee colonies, Behav. Ecol. Sociobiol. 28, 61-76.

Camazine S. (1993) The regulation of pollen foraging by honey bees: How foragers assess the colony's need for pollen, Behav. Ecol. Sociobiol. 32, 265273.

Camazine S., Sneyd J., Jenkins J., Murray J.D. (1990) A mathematical model of self-organized pattern formation on the combs of honeybee colonies, J. Theor. Biol. 147, 553-571.

Camazine S., Crailsheim K., Hrassnigg N., Robinson G.E., Leonhard B., Kropiunigg H. (1998) Protein trophallaxis and the regulation of pollen foraging by honey bees (Apis mellifera L.), Apidologie 29, $113-126$.

Crailsheim K. (1990) Protein synthesis in the honeybee (Apis mellifera L.) and trophallactic distribution of jelly among imagos in laboratory experiments, Zool. Jb. Physiol. 94, 303-312.

Crailsheim K. (1991) Interadult feeding of jelly in honeybee (Apis mellifera L.) colonies, J. Comp. Physiol. B 161, 55-60.

Crailsheim K. (1992) The flow of jelly within a honeybee colony, J. Comp. Physiol. B 162, 681689.

Crailsheim K. (1998) Trophallactic interactions in the adult honeybee (Apis mellifera L.), Apidologie 29, 97-112.

Crailsheim K., Schneider L.H.W., Hrassnigg N., Bühlmann G., Brosch U., Gmeinbauer R., Schöffmann B. (1992) Pollen consumption and utilization in worker honeybees (Apis mellifera carnica): Dependence on individual function and age, J. Insect Physiol. 38, 409-419.

Crailsheim K., Riessberger U., Blaschon B., Nowogrodzki R., Hrassnigg N. (1999) Short-term effects of simulated bad weather conditions upon the behaviour of food-storer honeybees during day and night (Apis mellifera carnica Pollmann), Apidologie 30, 299-310.

DeGrandi-Hoffman G., Hagler J. (2000) The flow of incoming nectar through a honey bee (Apis mellifera L.) colony as revealed by a protein marker, Insectes Soc. 47, 302-306.

De Marco R.J., Farina W.M. (2003) Trophallaxis in forager honeybees (Apis mellifera): Resource uncertainty enhances begging contacts, J. Comp. Physiol. A 189, 125-134.

Dietz A., Stephenson S.P. (1975) The effect of long term storage on the nutritive value of pollen for brood rearing of honey bees, Am. Bee J. 476-477.

Doull K.M. (1974) Effect of distance on the attraction of pollen to honeybees in the hive, J. Apic. Res. $13,27-32$.

Doull K.M., Standifer L.N. (1969) A technique for measuring feeding responses of honeybees in their hive, J. Apic. Res. 8, 153-157.

Doull K.M., Standifer L.N. (1970) Feeding responses of honeybees in the hive, J. Apic. Res. 9, 129132.

Dreller C., Tarpy D.R. (2000) Perception of the pollen need by foragers in a honeybee colony, Anim. Behav. 59, 91-96.

Dustmann J.H., von der Ohe W. (1988) Einfluß von Kälteeinbrüchen auf die Frühjahrsentwicklung von Bienenvölkern (Apis mellifera L.), Apidologie 19, 245-254.

Eischen F.A., Rothenbuhler W.C., Kulincevic J.M. (1982) Length of life and dry weight of worker honeybees reared in colonies with different worker-larva ratios, J. Apic. Res. 21, 19-25.

Eischen F.A., Rothenbuhler W.C., Kulincevic J.M. (1983) Brood rearing associated with a range of worker-larva ratios in the honeybee, J. Apic. Res. 22, 163-168.

Eischen F.A., Rothenbuhler W.C., Kulincevic J.M. (1984) Some effects of nursing on nurse bees, J. Apic. Res. 23, 90-93. 
Fewell J.H., Winston M.L. (1992) Colony state and regulation of pollen foraging in the honey bee, Apis mellifera L., Behav. Ecol. Sociobiol. 30, 387-393.

Filmer R.S. (1932) Brood area and colony size as factors in activity of pollination units, J. Econ. Entomol. 25, 336-343.

Free J.B. (1957a) The food of adult drone honeybees (Apis mellifera)., Brit. J. Anim. Behav. 5, 7-11.

Free J.B. (1957b) The transmission of food between worker honeybees, Brit. J. Anim. Behav. 5, 41-47.

Free J.B. (1960) The distribution of bees in a honeybee (Apis mellifera L.) colony, Proc. R. Entomol. Soc. London Ser. A 35, 141-144.

Free J.B. (1967) Factors determining the collection of pollen by honeybee foragers, Anim. Behav. 15, 134-144.

Free J.B., Williams I.H. (1971) The effect of giving pollen and pollen supplement to honeybee colonies on the amount of pollen collected, J. Apic. Res. 10, 87-90.

Free J.B., Winder M.E. (1983) Brood recognition by honeybee (Apis mellifera) workers, Anim. Behav. 31, 539-545.

Fukuda H. (1983) The relationship between work efficiency and population size in a honeybee colony, Res. Pop. Ecol. 25, 249-263.

Fukuda H., Sakagami S.F. (1968) Worker brood survival in honeybees, Res. Pop. Ecol. 10, 31-39.

Furgala B., Boch R. (1961) Distribution of honeybees on brood, Bee World 42, 200-202.

Garofalo C.A. (1977) Brood viability in normal colonies of Apis mellifera, J. Apic. Res. 16, 3-13.

Hanser G., Rembold H. (1964) Analytische und histologische Untersuchungen der Kopf- und Thoraxdrüsen bei der Honigbiene Apis mellifica, Z. Naturforsch. 19b, 938-943.

Harbo J.R. (1986) Effect of population size on brood production, worker survival and honey gain in colonies of honeybees, J. Apic. Res. 25, 22-29.

Harbo J.R. (1993) Effect of brood rearing on honey consumption and the survival of worker honey bees, J. Apic. Res. 32, 11-17.

Hart A.G., Ratnieks F.L.W. (2001) Why do honeybee (Apis mellifera) foragers transfer nectar to several receivers? Information improvement through multiple sampling in a biological system, Behav. Ecol. Sociobiol. 49, 244-250.

Haydak M.H. (1935) Brood rearing by honeybees confined to a pure carbohydrate diet, J. Econ. Entomol. 28, 657-660.

Haydak M.H. (1963a) Age of nurse bees and brood rearing, J. Apic. Res. 2, 101-103.

Haydak M.H. (1963b) Influence of storage on the nutritive value of pollen for brood rearing by honeybees, J. Apic. Res. 2, 105-107.

Haydak M.H. (1970) Honey bee nutrition, Annu. Rev. Entomol. 15, 143-156.

Hellmich R.L. II, Rothenbuhler W.C. (1986a) Pollen hoarding and use by high and low pollen- hoarding honeybees during the course of brood rearing, J. Apic. Res. 25, 30-34.

Hellmich R.L. II, Rothenbuhler W.C. (1986b) Relationship between different amounts of brood and the collection and use of pollen by honey bee (Apis mellifera), Apidologie 17, 13-20.

Hess W.R. (1926) Die Temperaturregulierung im Bienenvolk, Z. Vergl. Physiol. 4, 465-487.

Himmer A. (1932) Die Temperaturverhältnisse bei den sozialen Hymenopteren, Biol. Rev. 7, 224 253

Huang Z.-Y., Otis G.W. (1991a) Nonrandom visitation of brood cells by worker honey bees (Hymenoptera: Apidae), J. Insect Behav. 4, 177184.

Huang Z.-Y., Otis G.W. (1991b) Inspection and feeding of larvae by worker honey bees (Hymenoptera: Apidae): Effect of starvation and food quantity, J. Insect Behav. 4, 305-317.

Huang Z.-Y., Robinson G.E. (1996) Regulation of honey bee division of labor by colony age demography, Behav. Ecol. Sociobiol. 39, $147-$ 158.

Janmaat A.F., Winston M.L. (2000) The influence of pollen storage area and Varroa jacobsoni Oudemans parasitism on temporal caste structure in honey bees (Apis mellifera L.), Insectes Soc. 47, 177-182.

Janmaat A.F., Winston M.L., Ydenberg R.C. (2000) Condition-dependent response to changes in pollen stores by honey bee (Apis mellifera) colonies with different parasitic loads, Behav. Ecol. Sociobiol. 47, 171-179.

Jaycox E.R. (1970) Honey bee foraging behavior: Responses to queens, larvae and extracts of larvae, Ann. Entomol. Soc. Am. 63, 1689-1694.

Korst P.J.A.M., Velthuis H.H.W. (1982) The nature of trophallaxis in honeybees, Insectes Soc. 29, 209-221.

Kugler P.N., Turvey M.T. (1988) Self-organization, flow fields and information, Hum. Mov. Sci. 7, 97-129.

Le Conte Y., Sreng L., Poitout S.H. (1995) Brood pheromone can modulate the feeding behavior of Apis mellifera workers (Hymenoptera: Apidae), J. Econ. Entomol. 88, 798-804.

Lindauer M. (1952) Ein Beitrag zur Frage der Arbeitsteilung im Bienenstaat, Z. Vergl. Physiol. 34, 299-345.

Lineburg B. (1924) The feeding of honeybee larvae, Bull. U.S. Dept. Agric. 1222, 25-37.

Merill J.H. (1924) Sealed and unsealed brood, Am. Bee J. 64, 424-425.

Moeller F.E. (1972) Honey bee collection of corn pollen reduced by feeding pollen in the hive, Am. Bee J. 112, 210-212.

Moritz R.F.A., Hallmen M. (1986) Trophallaxis of worker honeybees (Apis mellifera L.) of different ages, Insectes Soc. 33, 26-31.

Myser W.C. (1952) Ingestion of eggs by honey bee workers, Am. Bee J. 92, 67. 
Newton D.C., Michl D.J. (1974) Cannibalism as an indication of pollen insufficiency in honeybees: ingestion of recapping of manually exposed pupae, J. Apic. Res. 13, 235-241.

Nixon H.L., Ribbands C.R. (1952) Food transmission within the honeybee community, Proc. R. Soc. Brit. 140, 43-50.

Page R.E. Jr., Fondrk M.K. (1995) The effect of colony-level selection on the social organization of honey bee (Apis mellifera L.) colonies: colonylevel components of pollen hoarding, Behav. Ecol. Sociobiol. 36, 135-144.

Page R.E. Jr., Waddington K.D., Hunt G.J., Fondrk M.K. (1995) Genetic determinants of honey bee foraging behaviour, Anim. Behav. 50, 16171625 .

Pankiw T., Page R.E. Jr. (2001) Genotype and colony environment affect honeybee (Apis mellifera L.) development and foraging behavior, Behav. Ecol. Sociobiol. 51, 87-94.

Pankiw T., Page R.E. Jr., Fondrk M.K. (1998) Brood pheromone stimulates pollen foraging in honey bees (Apis mellifera), Behav. Ecol. Sociobiol. 44, 193-198.

Pankiw T., Tarpy D.R., Page R.E. Jr. (2002) Genotype and rearing environment affect honeybee perception and foraging behaviour, Anim. Behav. 64, 663-672.

Pernal S.F., Currie R.W. (2001) The influence of pollen quality on foraging behavior in honeybees (Apis mellifera L.), Behav. Ecol. Sociobiol. 51, 53-68.

Pernal S.F., Currie R.W. (2002) Discrimination and preferences for pollen-based cues by foraging honeybees, Apis mellifera L., Anim. Behav. 63, 369-390.

Ratnieks F.L.W. (1993) Egg-laying, egg-removal, and ovary development by workers in queenright honey bee colonies, Behav. Ecol. Sociobiol. 32, 191-198.

Ratnieks F.L.W., Anderson C. (1999) Task partitioning in insect societies. II. Use of queueing delay information in recruitment, Am. Nat. 154, 536548.

Renner P., Hrassnigg N., Crailsheim K. (2003) Trophallaxis between nurse bees and pollen foragers under laboratory conditions in Apis mellifera carnica, Apidologie 34, 492-493.

Ribeiro M.F. (1994) Growth in bumble bee larvae: relation between development time, mass, and amount of pollen ingested, Can. J. Zool. 72, 1978-1985.

Ribeiro M.F., Velthuis H.H.W., Duchateau M.J., van der Tweel I. (1999) Feeding frequency and caste differentiation in Bombus terrestris larvae, Insectes Soc. 46, 306-314.

Robinson G.E. (1987) Regulation of honey bee age polyethism by juvenile hormone, Behav. Ecol. Sociobiol. 20, 329-338.

Robinson G.E., Page R.E. Jr., Strambi C., Strambi A. (1989) Hormonal and genetic control of behavioral integration in honey bee colonies, Science 246, 109-112.
Robinson G.E., Page R.E. Jr., Strambi C., Strambi A. (1992) Colony integration in honey bees: Mechanisms of behavioral reversion, Ethology 90, 336348.

Rösch G.A. (1925) Untersuchungen über die Arbeitsteilung im Bienenstaat. I. Die Tätigkeiten im normalen Bienenstaate und ihre Beziehungen zum Alter der Arbeiterinnen, Z. Vergl. Physiol. 2, 571-631.

Rothenbuhler W.C., Page R.E. Jr. (1989) Genetic variability for temporal polyethism in colonies consisting of similarly-aged worker honey bees, Apidologie 29, 433-437.

Rotjan R.D., Calderone N.W., Seeley T.D. (2002) How a honey bee colony mustered additional labor for the task of pollen foraging, Apidologie $33,367-373$.

Sakagami S.F. (1953) Untersuchungen über die Arbeitsteilung in einem Zwergvolk der Honigbiene. Beiträge zur Biologie des Bienenvolkes, Apis mellifera L. I., Jpn J. Zool. 11, 117-185.

Schmickl T., Crailsheim K. (2001) Cannibalism and early capping: strategies of honeybee colonies in times of experimental pollen shortages, J. Comp. Physiol. A 187, 541-547.

Schmickl T., Crailsheim K. (2002) How honeybees (Apis mellifera L.) change their broodcare behaviour in response to non-foraging conditions and poor pollen conditions, Behav. Ecol. Sociobiol. 51, 415-425.

Schmickl T., Blaschon B., Gurmann B., Crailsheim K. (2003) Collective and individual nursing investment in the queen and in young and old honeybee larvae during foraging and nonforaging periods, Insectes Soc. 50, 174-184.

Schulz D.J., Huang Z.-Y., Robinson G.E. (1998) Effects of colony food shortage on behavioral development in honey bees, Behav. Ecol. Sociobiol. 42, 295-303.

Schulz D.J., Vermiglio M.J., Huang Z.-Y., Robinson G.E. (2002) Effects of colony food shortage on social interactions in honey bee colonies, Insectes Soc. 49, 50-55.

Seeley T.D. (1982) Adaptive significance of the age polyethism schedule in honeybee colonies, Behav. Ecol. Sociobiol. 11, 287-293.

Seeley T.D. (1989) Social foraging in honey bees: how nectar foragers assess their colony's nutritional status, Behav. Ecol. Sociobiol. 24, 181-199.

Seeley T.D. (1994) Honey bee foragers as sensory units of their colonies, Behav. Ecol. Sociobiol. 34, 51-62.

Seeley T.D., Tovey C.A. (1994) Why search time to find a food-storer bee accurately indicates the relative rates of nectar collecting and nectar processing in honey bee colonies, Anim. Behav. 47, 311-316.

Seeley T.D., Camazine S., Sneyd J. (1991) Collective decision-making in honey bees: how colonies choose among nectar sources, Behav. Ecol. Sociobiol. 28, 277-290. 
Simpson J., Greenwood S.P. (1975) Results of restricting the brood space of honeybee colonies, J. Apic. Res. 14, 51-55.

Smith M.V. (1974) Relationship of age to brood-rearing activities of worker honey bees, Apis mellifera L., Proc. Entomol. Soc. Ont. 105, 128-132.

Southwick E.E. (1987) Cooperative metabolism in honey bees: An alternative to antifreeze and hibernation, J. Therm. Biol. 12, 155-158.

Southwick E.E. (1991) The colony as a thermoregulating superorganism, in: Goodmann L.J., Fischer R.C. (Eds.), The behaviour and physiology of bees, C.A.B. International, Wallingford, pp. 2847.

Southwick E.E., Heldmaier G. (1987) Temperature control in honey bee colonies, BioScience 37 , 395-399.

Stabe H.A. (1930) The rate of growth of worker, drone and queen larvae of the honeybee, Apis mellifera Linn., J. Econ. Entomol. 23, 447-453.

Starks P.T., Gilley D.C. (1999) Heat shielding: A novel method of colonial thermoregulation in honey bees, Natuwissenschaften 86, 438-440.

Starks P.T., Blackie C.A., Seeley T.D. (2000) Fever in honeybee colonies, Naturwissenschaften 87, 229-231.

Sumpter D.J.T., Pratt S.C. (2003) A modelling framework for understanding social insect foraging, Behav. Ecol. Sociobiol. 53, 131-144.

Szabo T.I. (1980) Effect of weather factors on honeybee flight activity and colony weight gain, J. Apic. Res. 19, 164-171.

Taber S. (1973) Influence of pollen location in the hive on its utilization by the honeybee colony, J. Apic. Res. 12, 17-20.

Thierry B., Theraulaz G., Gautier J.Y., Stiegler B. (1996) Joint memory, Behav. Proc. 35, 127-140.

Varjú D., Núnez J. (1991) What do foraging honeybees optimize? J. Comp. Physiol. A 169 , 729-736.

Vaughan D.M., Calderone N.W. (2002) Assessment of pollen stores by foragers in colonies of the honey bee, Apis mellifera L., Insectes Soc. 49, 23-27.

Villa J.D., Gentry C., Taylor O.R. Jr. (1987) Preliminary observations on thermoregulation, clustering, and energy utilization in African and European honey bees, J. Kans. Entomol. Soc. 60, 414.
Wainselboim A.J., Farina W.M. (2000) Trophallaxis in the honeybee Apis mellifera (L.): the interaction between flow of solution and sucrose concentration of the exploited food sources, Anim. Behav. 59, 1177-1185.

Waldbauer G.P., Friedman S. (1991) Self-selection of optimal diets by insects, Annu. Rev. Entomol. 36, 43-63.

Wang D.-I. (1965) Growth rates of young queen and worker honeybee larvae, J. Apic. Res. 4, 3-5.

Webster T.C., Peng Y.-S. (1987) Passage of cannibalized tissue among honey bee (Hymenoptera: Apidae) colony members, Ann. Entomol. Soc. Am. 80, 814-819.

Webster T.C., Thorp R.W., Briggs D., Skinner J., Parisian T. (1985) Effects of pollen traps on honey bee (Hymenoptera: Apidae) foraging and brood rearing during almond and prune pollination, Environ. Entomol. 14, 683-686.

Webster T.C., Peng Y.-S., Duffey S.S. (1987) Conservation of nutrients in larval tissue by cannibalizing honey bees, Physiol. Entomol. 12, 225-231.

Weidenmüller A., Tautz J. (2002) In-Hive behavior of pollen foragers (Apis mellifera) in honey bee colonies under conditions of high and low pollen need, Ethology 108, 205-221.

Weiss K. (1984) Regulierung des Proteinhaushaltes im Bienenvolk (Apis mellifera L.) durch Brutkannibalismus, Apidologie 15, 339-354.

Winston M.L., Punnett E.N. (1982) Factors determining temporal division of labor in honeybees, Can. J. Zool. 60, 2947-2952.

Winston M.L., Fergusson L.A. (1985) The effect of worker loss on temporal caste structure in colonies of the honeybee (Apis mellifera L.), Can. J. Zool. 63, 777-780.

Winston M.L., Fergusson L.A. (1986) Influence of the amount of eggs and larvae in honeybee colonies on temporal division of labour, J. Apic. Res. 25, 238-241.

Woyke J. (1977) Cannibalism and brood-rearing efficiency in the honey bee, J. Apic. Res. 16, 8494.

Woyke J. (1988) Brood survival in productive bee apiaries in Australia as a test for breeding honeybees in closed populations, J. Apic. Res. 27, 30-34. 